\title{
Evaluating the Employability Skills towards Performance of Industrial Employees
}

\author{
C. Anitha, K.V.R.Rajandran
}

\begin{abstract}
In the globalization era, Industrial sector is hunting for highly skilled employees for usage of modern technology. Beside, the academic qualification the employers prefer the advance skilled labors in the industrial sector. The employability skills is not only needed for to obtain job, but it is also essentially need to explore the good progress, and for to sustain in the working environment, The purpose of this study is to examine the employability skills, which was developed by employee to enhance the performance of the worker. The researcher adopted a descriptive analysis for this research. The researcher collected the data by using simple random sampling technique with structured questionnaires. 260 was the sample size. The study is plan among the industrial employees in Tiruchirappalli Districts .The statistical technique tools as factor analysis, correlation and multiple regression were been used for analyzing the data. The outcome of the research will show the current status of industrial employee's employability skills. Further the research would help the employers to understand the employee status and way to handle the lacking skills which would be very helpful to upgrade the employees and industries together.
\end{abstract}

Index Terms: Employee, Employer, Employability skills, Working Environment, Employee Performance, Tiruchirappalli, Tamil Nadu.

\section{INTRODUCTION}

The employability skills are incredibly important for the successive platform of the Industrial sector. Employability skills are manageable core skill groups that represent fundamental functional and enabling knowledge, skills and attitudes required by the $21^{\text {st }}$ century work place (Overtoom, 2000). In this technological era the Industries were required of high skilled employees for their sustainable growth. Moreover the advance technology may influence the demand of skilled employees. Robinson (2000), affirmed employability skills as "those basic skills necessary for getting, keeping, and doing well on a job". Thus, the role of employability skills in industries is vital for the individual employee growth. There are several researches on employability skills have been carried out both nationally and internationally, and it reveale that presently many technical graduates are lack of employability skills compare to their technical skills (Rasul et.al, 2010). The employability skills are required for the employee to sustain and get promotion in their jobs. This study is fully concentrated on the self evaluation of the employability skills of industrial employees towards their performance. The study majorly focused on six important elements of the employability skills, they are

Revised Manuscript Received on July 05, 2019.

Anitha.C, Department of Management Studies, Periyar Maniammai Institute of Science \& Technology, Thanjavur, India

KVR Rajandran, Department of Management Studies, Periyar Maniammai Institute of Science \& Technology, Thanjavur, India planning and organizing skills, self management skills, team work skills, communication skills, problem solving skills, technological skills. The self evaluation of employability skills by industrial employees helps them to improve their lacking area towards their performance. The implications of this study will be supportive in directing industry enhancing these skills between professionals.

\section{LITERATURE REVIEW}

Vidya and Kartik (2015) studied the reason of the employability skills and its position of industry. The researcher collected 100 sample sizes. The factor analysis was used to evaluate the data statistically. The researcher agreed that the factors were influencing on employability skills in India. The researched said that the employability skills strategies performed by the human resources could benefit all stakeholders and assist for overall economy.

Samson and Rajagopal (2014) described the employability skills conceptual framework among business graduates in Coimbatore. The researcher analyzed from the secondary data of (1994-2013) employee skills and performance. The researcher found that curricular changes enhance employability skills of the business graduates.

Divya (2012) analyzed about employability skill among professionals and HR executives in Indian labor market: the studied on engineering graduates of Bhopal .The intention of the study was, to classify the level of employability skill among employee. Its differences based on the respondents' demography details and to facilitate suggestive measure in this regard. The data was analyzed by T-test. The study accomplished that the redesigning of the university set of courses with more apprenticeship and industry projects will facilitate the pre job training which will surely develop the employability among employees.

Faizenabi (2013) described on the management student's self-perception towards their employability skills a pre and post soft skills training analysis. 120 was the sample size. The data was analyzed using factor analysis, correlation and regression analysis. Management students had self-perception towards their employability skills a pre and post soft skills training analysis.

Johnny (2013) studied the nature of employability skills and empirical evidence of the employee for success in the workplace at Singapore. The research was conducted by the institute for adult learning center in Singapore. The sample

size of the study was 239 respondents. The researchers used frequency distribution and factory analysis for to evaluate the data. The employability skills debated and as well as implications for policy development. The most 
important learning points the link between job and employability depends on the job context involved especially on employability skills.

\section{METHODOLOGY}

\section{A. Research Design}

The study was conducted in Tiruchirappalli District, Industrial Region. The sample population was 840. The sample size of the study was calculated by using online Rao software with 5\% margin error and $95 \%$ of confidence level. The secondary data was retrieved from the journals, articles, websites, thesis, e-books, books etc. The simple random sampling technique was used in the research to collect data. The researcher used structured questionnaire as research tool for the study. The questions were enclosed in 5 point Likert scale method. (1 - Strongly Agree, 2 - Agree, 3 - Neutral, 4 Disagree, 5 - Strongly Disagree).

\section{B. Objectives of the study}

- To analyze the relationship between the self management skills and employee performance of the industrial employee

- To measure the impact of employability skills on employee performance

- To identify the factors influencing the employability skills in the industrial employees

\section{Variables used in the study:}

(i) Dependent Variable: Employee Performance

(ii) Independent Variable: Employability Skills

\begin{tabular}{|c|l|c|l|}
\hline \multicolumn{4}{|c|}{ Employability Skills Factors } \\
\hline S.No & \multicolumn{1}{|c|}{ Factors } & & \multicolumn{1}{c|}{ Variables } \\
\hline 1. & $\begin{array}{l}\text { Planning and } \\
\text { Organizational } \\
\text { skills }\end{array}$ & 1 & $\begin{array}{l}\text { Planning and } \\
\text { organizational skills is } \\
\text { first step in } \\
\text { employability skills } \\
\text { prediction (POS 1) }\end{array}$ \\
\hline & 2 & $\begin{array}{l}\text { Manage the tasks } \\
\text { successfully (POS 2) }\end{array}$ \\
\hline & 3 & $\begin{array}{l}\text { Motivation and ultimate } \\
\text { success (POS 3) }\end{array}$ \\
\hline 2. & $\begin{array}{l}\text { Self Management } \\
\text { Skills }\end{array}$ & 6 & $\begin{array}{l}\text { Time management and } \\
\text { planning (POS 4) }\end{array}$ \\
\hline & & 7 & $\begin{array}{l}\text { Increase self-motivation } \\
\text { and potentially future } \\
\text { success (POS 5) }\end{array}$ \\
\hline & & $\begin{array}{l}\text { Own behavior on a } \\
\text { of behaviors (SMS 2) }\end{array}$ \\
\hline
\end{tabular}

\begin{tabular}{|c|c|c|c|}
\hline & & 8 & $\begin{array}{l}\text { Positive results/reviews } \\
\text { (SMS 3) }\end{array}$ \\
\hline & & 9 & Self-monitoring (SMS 4) \\
\hline & & 10 & Self-evaluation (SMS 5) \\
\hline \multirow[t]{5}{*}{3.} & Team work skills & 11 & $\begin{array}{l}\text { Teamwork abilities } \\
\text { (TWS 1) }\end{array}$ \\
\hline & & 12 & $\begin{array}{l}\text { High level of } \\
\text { cooperation within my } \\
\text { team (TWS 2) }\end{array}$ \\
\hline & & 13 & $\begin{array}{l}\text { All team members } \\
\text { treated me fairly (TWS } \\
\text { 3) }\end{array}$ \\
\hline & & 14 & $\begin{array}{l}\text { Teamwork goals (TWS } \\
\text { 4) }\end{array}$ \\
\hline & & 15 & $\begin{array}{l}\text { Satisfied with } \\
\text { performance of my team } \\
\text { (TWS 5) }\end{array}$ \\
\hline \multirow[t]{4}{*}{4.} & $\begin{array}{l}\text { Communication } \\
\text { skills }\end{array}$ & 16 & Oral (CS 1) \\
\hline & & 17 & Written (CS 2) \\
\hline & & 18 & $\begin{array}{l}\text { Good Communication } \\
\text { (CS 3) }\end{array}$ \\
\hline & & 19 & $\begin{array}{l}\text { Patient Communication } \\
\text { (CS 4) }\end{array}$ \\
\hline \multirow[t]{5}{*}{5.} & Problem solving & 20 & Very effective (PS 1) \\
\hline & & 21 & $\begin{array}{l}\text { No rules for problem } \\
\text { solving (PS 2) }\end{array}$ \\
\hline & & 22 & $\begin{array}{l}\text { Good level of } \\
\text { collaboration helps } \\
\text { problem solving (PS 3) }\end{array}$ \\
\hline & & 23 & Experience (PS 4) \\
\hline & & 24 & $\begin{array}{l}\text { Find the solution, at least } \\
\text { in the tasks of the } \\
\text { retrieval of unusual } \\
\text { words and rebus } \\
\text { problem solving (PS 5) }\end{array}$ \\
\hline \multirow[t]{3}{*}{6.} & $\begin{array}{l}\text { Technological } \\
\text { Skills }\end{array}$ & 25 & $\begin{array}{l}\text { The technology skills } \\
\text { has not used for all the } \\
\text { area (TS 1) }\end{array}$ \\
\hline & & 26 & $\begin{array}{l}\text { Improve our knowledge } \\
\text { (TS 2) }\end{array}$ \\
\hline & & 27 & Daily life (TS 3) \\
\hline
\end{tabular}




\begin{tabular}{|l|l|c|l|}
\hline & 28 & $\begin{array}{l}\text { Employee motivation } \\
\text { (TS 4) }\end{array}$ \\
\hline & 29 & $\begin{array}{l}\text { Struggling employees } \\
\text { (TS 5) }\end{array}$ \\
\hline
\end{tabular}

\section{Statistical Tools:}

The researcher used the statistical test to evaluate the data. The following statistical test were followed in this research,

- Pearson Correlations

- Multiple Regressions

- Factor Analysis

The data analysis was done through IBM SPSS20 Packages and SPSS (AMOS23).

\section{E. Hypothesis of the study:}

\begin{tabular}{|c|c|c|}
\hline Hypothesis & HO & Hypothesis of the statement \\
\hline Hypothesis 1 & $\mathrm{H} 0$ & $\begin{array}{l}\text { There is no significant relationship } \\
\text { between the Self Management } \\
\text { Skills and employee performance }\end{array}$ \\
\hline Hypothesis 2 & $\mathrm{H} 0$ & $\begin{array}{l}\text { There is no impact between the } \\
\text { employability skills and employee } \\
\text { performance }\end{array}$ \\
\hline Hypothesis 3 & $\mathrm{H} 0$ & $\begin{array}{l}\text { There is no significant relationship } \\
\text { between the positive } \\
\text { results/reviews and employee } \\
\text { performance }\end{array}$ \\
\hline Hypothesis 4 & $\mathrm{H} 0$ & $\begin{array}{l}\text { There is no significant relationship } \\
\text { between the self-monitoring and } \\
\text { employee performance }\end{array}$ \\
\hline Hypothesis 5 & $\mathrm{H} 0$ & $\begin{array}{l}\text { There is no significant relationship } \\
\text { between the self-evaluation and } \\
\text { employee performance }\end{array}$ \\
\hline Hypothesis 6 & Ho & $\begin{array}{l}\text { There is no impact between the } \\
\text { planning and organizational skills } \\
\text { and employee performance }\end{array}$ \\
\hline Hypothesis 7 & $\mathrm{H} 0$ & $\begin{array}{l}\text { There is no impact between the self } \\
\text { management skills and employee } \\
\text { performance }\end{array}$ \\
\hline Hypothesis 8 & $\mathrm{H} 0$ & $\begin{array}{l}\text { There is no impact between the } \\
\text { team work skills and employee } \\
\text { performance }\end{array}$ \\
\hline Hypothesis 9 & $\mathrm{H} 0$ & $\begin{array}{l}\text { There is no impact between the } \\
\text { communication skills and } \\
\text { employee performance }\end{array}$ \\
\hline Hypothesis 10 & $\mathrm{H} 0$ & $\begin{array}{l}\text { There is no impact between the } \\
\text { problem solving skills and } \\
\text { employee performance }\end{array}$ \\
\hline Hypothesis 11 & $\mathrm{H} 0$ & There is no impact between the \\
\hline
\end{tabular}

technological skills and employee performance

\section{DATA ANALYSIS AND INTERPRETATIONS:}

\section{A. Correlation Analysis}

Table 1: The Correlations Test of relationship between self management skills and employee performance

\begin{tabular}{|c|c|c|c|}
\hline Variables & $\begin{array}{c}\text { Pearson } \\
\text { Correlation }\end{array}$ & Significance & N \\
\hline SMS 1 & $.382 * *$ & 0 & 260 \\
\hline SMS 2 & $.502 * *$ & 0 & 260 \\
\hline SMS 3 & $.804 * *$ & 0 & 260 \\
\hline SMS 4 & $.253 * *$ & 0 & 260 \\
\hline SMS 5 & $.139 *$ & 0.025 & 260 \\
\hline
\end{tabular}

The table 1 shows that the relationship between self management skills and employee performance. The result reveals that the SMS 1, SMS 2, SMS 3, SMS 4 was a strong, positive correlation between employee performance, which was statistically highly significant $(\mathrm{P}-$ Value $<0.001)$ with Pearson correlation $\mathrm{r}$ value of $0.382,0.502,0.804,0.253$ respectively. Moreover the SMS 5 was also positively correlated with the employee performance with statistically significant ( $\mathrm{P}$ value is 0.025 which is $<0.05)$ and Pearson correlation $\mathrm{r}$ value is 0.139 .

\section{B. Multiple Regressions Analysis for employability skills:}

Table 2: Multiple determination of $\mathrm{R}^{2}$ coefficient of Multiple linear Regression

\begin{tabular}{|l|c|}
\hline $\mathrm{R}$ & $.978^{\mathrm{a}}$ \\
\hline $\mathrm{R}$ Square & .956 \\
\hline $\begin{array}{l}\text { Std. Error of the } \\
\text { Estimate }\end{array}$ & .252 \\
\hline
\end{tabular}

The coefficient of multiple determinations is 0.956; therefore, about $95.6 \%$ of the variation in the employee performance is explained by employability skills. The regression equation appears to be very useful for making predictions since the value of $\mathrm{R} 2$ is close to 1

Table 3: Anova

\begin{tabular}{|l|l|l|l|}
\hline & Regression & Residual & Total \\
\hline Sum of Squares & 317.43 & 14.633 & 332.06 \\
\hline Df & 29 & 230 & 259 \\
\hline Mean Square & 10.95 & .064 & \\
\hline F & 172.046 & & \\
\hline Significance & $.000^{\mathrm{a}}$ & & \\
\hline
\end{tabular}

The regression ANOVA table 3 shows that the significance value is $<0.001$ with $\mathrm{F}$ value $=172.046$. The table reveals that the employability skills have strong prediction on the employee performance.

Table 4: Multiple Regression Coefficients table 


\begin{tabular}{|c|c|c|c|c|c|c|}
\hline \multicolumn{7}{|c|}{ Coefficients ${ }^{\mathrm{a}}$} \\
\hline \multirow{2}{*}{\multicolumn{2}{|c|}{ Model }} & \multicolumn{2}{|c|}{$\begin{array}{l}\text { Unstandardized } \\
\text { Coefficients }\end{array}$} & \multirow{2}{*}{$\begin{array}{c}\text { Standa } \\
\text { rdized } \\
\text { Coeffic } \\
\text { ients }\end{array}$} & \multirow[b]{2}{*}{$\mathrm{t}$} & \multirow[b]{2}{*}{ Sig. } \\
\hline & & B & $\begin{array}{l}\text { Std. } \\
\text { Error }\end{array}$ & & & \\
\hline \multirow[t]{30}{*}{1} & \begin{tabular}{|l|} 
(Const \\
ant)
\end{tabular} & 0.363 & 0.191 & & 1.898 & 0.059 \\
\hline & POS 1 & 0.059 & 0.028 & 0.046 & 2.134 & 0.034 \\
\hline & POS 2 & 0.001 & 0.035 & 0.001 & 0.031 & 0.976 \\
\hline & POS 3 & 0.061 & 0.03 & 0.048 & 2.046 & 0.042 \\
\hline & POS 4 & 0.058 & 0.029 & 0.04 & 2.021 & 0.044 \\
\hline & POS 5 & $\begin{array}{r}-0.07 \\
3\end{array}$ & 0.021 & -0.067 & $\begin{array}{r}-3.42 \\
2\end{array}$ & 0.001 \\
\hline & SMS 1 & 0.193 & 0.027 & 0.165 & 7.244 & 0.000 \\
\hline & SMS 2 & 0.229 & 0.026 & 0.189 & 8.711 & 0.000 \\
\hline & SMS 3 & 0.021 & 0.033 & 0.016 & 0.656 & 0.513 \\
\hline & SMS 4 & 0.076 & 0.056 & 0.08 & 1.349 & 0.179 \\
\hline & SMS 5 & 0.082 & 0.029 & 0.069 & 2.82 & 0.005 \\
\hline & TWS 1 & 0.012 & 0.029 & 0.011 & 0.419 & 0.676 \\
\hline & TWS 2 & 0.906 & 0.023 & 0.867 & $\begin{array}{r}39.78 \\
4\end{array}$ & 0.000 \\
\hline & TWS 3 & 0.017 & 0.03 & 0.017 & 0.543 & 0.587 \\
\hline & TWS 4 & 0.15 & 0.028 & 0.121 & 5.402 & 0.000 \\
\hline & TWS 5 & 0.42 & 0.18 & 0.295 & 2.337 & 0.020 \\
\hline & CS 1 & 0.998 & 0.067 & 0.752 & $\begin{array}{r}14.91 \\
5\end{array}$ & 0.000 \\
\hline & CS 2 & 0.206 & 0.051 & 0.156 & 4.046 & 0.000 \\
\hline & CS 3 & 0.148 & 0.034 & 0.113 & 4.411 & 0.000 \\
\hline & $\mathrm{CS} 4$ & 0.100 & 0.035 & 0.088 & 2.893 & 0.004 \\
\hline & PS 1 & 0.092 & 0.04 & 0.051 & 2.274 & 0.024 \\
\hline & PS 2 & 0.033 & 0.039 & 0.024 & 0.849 & 0.397 \\
\hline & PS 3 & 0.069 & 0.038 & 0.052 & 1.827 & 0.069 \\
\hline & PS 4 & 0.026 & 0.038 & 0.021 & 0.699 & 0.485 \\
\hline & PS 5 & 0.082 & 0.037 & 0.053 & 2.206 & 0.028 \\
\hline & TS 1 & 0.005 & 0.036 & 0.004 & 0.152 & 0.880 \\
\hline & TS 2 & 0.139 & 0.052 & 0.146 & 2.67 & 0.008 \\
\hline & TS 3 & 0.216 & 0.175 & 0.153 & 1.233 & 0.219 \\
\hline & TS 4 & 1.271 & 0.063 & 0.945 & $\begin{array}{r}20.03 \\
6\end{array}$ & 0 \\
\hline & TS 5 & 0.108 & 0.046 & 0.092 & 2.343 & 0.02 \\
\hline
\end{tabular}

From the table 4 the equation for the multiple regression model is derived as $\mathrm{Y}=\beta 0+\beta 1 \times 1+\beta 3 \times 3+\beta 4 \times 4+\beta 5 \times 5+\beta 6 \times 6+\beta 7 \times 7+\beta 10 \times 10+\beta 12 \times$ $12+\beta 14 \times 14+\beta 15 \times 15+\beta 16 \times 16+\beta 17 \times 17+\beta 18 \times 18+\beta 19 \times 19+\beta 2$ $0 \times 20+\beta 24 \times 24+\beta 26 \times 26+\beta 28 \times 28+\beta 29 \times 29$.
The table 4 reveals that the p-value of POS1, POS3, POS4, POS5, SMS1, SMS2, SMS5, TWS2, TWS4, TWS5, CS1, CS2, CS3, CS4, PS1, PS5, TS2, TS4, TS5 were less than 0.005 with significant value. This shows that therefore some strong evidence on influencing the employability skills have impact on the employee performance. High level of cooperation within my team (TMW 2) was highly influence with T-value of 39.784 among the independent predictors on the employee performance.

\subsection{Exploratory Factor Analysis:}

\begin{tabular}{|l|l|r|}
\hline \multicolumn{2}{|c|}{ Table 5 KMO and Bartlett's Test } \\
\hline \multicolumn{2}{|l|}{$\begin{array}{l}\text { Kaiser-Meyer-Olkin } \\
\text { Measure of Sampling }\end{array}$} \\
Adequacy. \\
\hline $\begin{array}{l}\text { Bartlett's } \\
\text { Test of } \\
\text { Sphericity }\end{array}$ & Approx. \\
& Chi-Square & 6.784 \\
\cline { 2 - 3 } & Df & 3 \\
\cline { 2 - 3 } & Sig. & 406 \\
\hline
\end{tabular}

The table 5 shows that the KMO is 0.784 , i.e. the value is more than 0.6 hence the variable were related to one another, with highly significance $\mathrm{p}$-value. This reveals that the items were fit for the factor analysis.

\section{Table 6 Total Variance}

\begin{tabular}{|c|c|c|c|c|c|c|c|}
\hline \multicolumn{8}{|c|}{ Total Variance Explained } \\
\hline $\mathrm{F}$ & \multicolumn{3}{|c|}{ Initial Eigen values } & \multicolumn{3}{|c|}{$\begin{array}{l}\text { Extraction Sums of } \\
\text { Squared Loadings }\end{array}$} & $\begin{array}{l}\text { Rotati } \\
\text { on } \\
\text { Sums } \\
\text { of } \\
\text { Squar } \\
\text { ed } \\
\text { Loadi } \\
\text { ngs }^{\mathrm{a}}\end{array}$ \\
\hline $\begin{array}{l}\mathrm{a} \\
\mathrm{c} \\
\mathrm{t} \\
\mathrm{o} \\
\mathrm{r}\end{array}$ & Total & $\begin{array}{c}\% \\
\text { of } \\
\text { Var } \\
\text { ian } \\
\text { ce }\end{array}$ & $\begin{array}{l}\text { Cum } \\
\text { ulati } \\
\text { ve \% }\end{array}$ & $\begin{array}{c}\text { Tot } \\
\text { al }\end{array}$ & $\begin{array}{c}\% \text { of } \\
\text { Varia } \\
\text { nce }\end{array}$ & $\begin{array}{c}\text { Cumu } \\
\text { lative } \\
\%\end{array}$ & Total \\
\hline 1 & $\begin{array}{r}9.88 \\
7\end{array}$ & $\begin{array}{r}34 . \\
094\end{array}$ & $\begin{array}{r}34.0 \\
94\end{array}$ & $\begin{array}{r}9.5 \\
46\end{array}$ & $\begin{array}{r}32.91 \\
9\end{array}$ & $\begin{array}{r}32.91 \\
9\end{array}$ & 5.212 \\
\hline 2 & $\begin{array}{r}3.49 \\
2\end{array}$ & $\begin{array}{r}12 . \\
042\end{array}$ & $\begin{array}{r}46.1 \\
36\end{array}$ & $\begin{array}{r}3.1 \\
17\end{array}$ & $\begin{array}{r}10.74 \\
7\end{array}$ & $\begin{array}{r}43.66 \\
6\end{array}$ & 3.559 \\
\hline 3 & $\begin{array}{r}2.29 \\
2\end{array}$ & $\begin{array}{r}7.9 \\
03\end{array}$ & $\begin{array}{r}54.0 \\
39\end{array}$ & $\begin{array}{r}1.9 \\
36\end{array}$ & 6.676 & $\begin{array}{r}50.34 \\
2\end{array}$ & 4.107 \\
\hline 4 & $\begin{array}{r}1.67 \\
1 \\
\end{array}$ & $\begin{array}{r}5.7 \\
61\end{array}$ & $\begin{array}{r}59.8 \\
01\end{array}$ & $\begin{array}{r}1.3 \\
71\end{array}$ & 4.726 & $\begin{array}{r}55.06 \\
8\end{array}$ & 5.772 \\
\hline 5 & $\begin{array}{r}1.50 \\
2\end{array}$ & $\begin{array}{r}5.1 \\
79 \\
\end{array}$ & $\begin{array}{r}64.9 \\
8\end{array}$ & $\begin{array}{r}1.1 \\
99\end{array}$ & 4.135 & $\begin{array}{r}59.20 \\
4\end{array}$ & 6.082 \\
\hline 6 & $\begin{array}{r}1.22 \\
8\end{array}$ & $\begin{array}{r}4.2 \\
36 \\
\end{array}$ & $\begin{array}{r}69.2 \\
16 \\
\end{array}$ & $\begin{array}{r}0.8 \\
38\end{array}$ & 2.889 & $\begin{array}{r}62.09 \\
3\end{array}$ & 2.69 \\
\hline 7 & $\begin{array}{r}1.04 \\
9\end{array}$ & $\begin{array}{r}3.6 \\
17\end{array}$ & $\begin{array}{r}72.8 \\
33\end{array}$ & & & & \\
\hline
\end{tabular}

Table 6 Total variance explained that the variables were classified into six factors. Further the table reveals that 
ISSN: 2277-3878, Volume-8 Issue-2S4, July 2019

the first six factors were together account of $62.093 \%$ of the total variance. The groups were named as Planning and Organizational skills, Self management skills, Team work skills, Communication skills, Problem solving skills and Technological skills. The first factor contains 5 items variance. The total Eigen value of second factor is 3.117 with 10.747 total variances and it consist of 5 items. The third factor contains of 2 items with total Eigen value of 1.936 with 6.76 of variance. The fourth factor contains of 4 items with total Eigen value of 1.371 with 4.726 of variance. The fifth factor contains of 5 items with total Eigen value of 1.99 with 10.747 of variance and sixth factor consist of 4 items with total Eigen value of 0.838 with 2.889 respectively.

Figure 1 Screen plot of factors

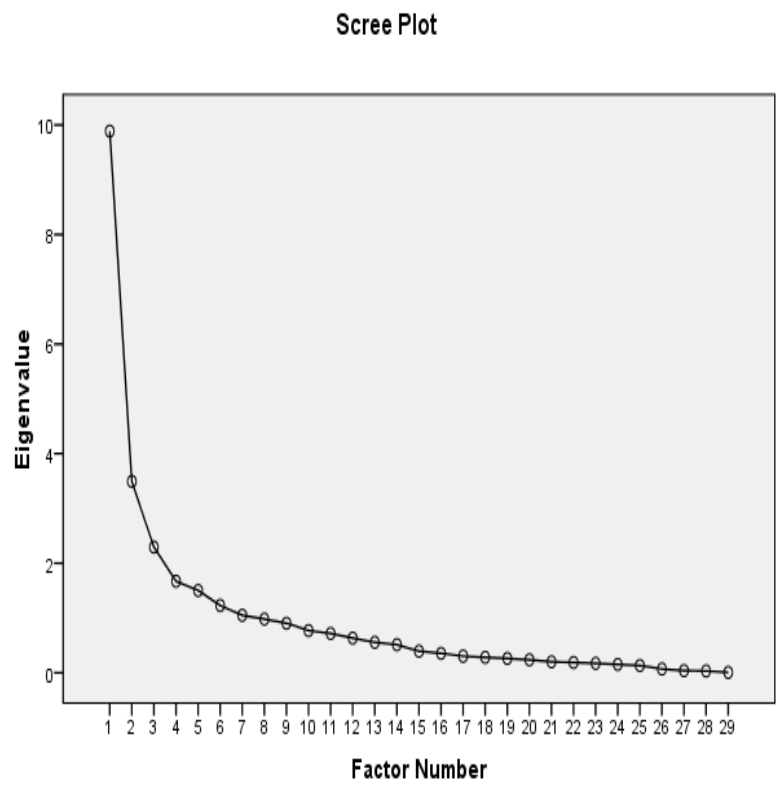

The figure 1 shows that screen plot of the factors were against the Eigen value. The figure shows that the each factor the first 5 columns of the curve exhibit above. Then, the $6^{\text {th }}$ column onwards the line almost gets flat. This reveals that the six factors are successive among the other total variances.

Table 7: The pattern matrix of factors influences that employability skill on employee performance. column (1) show the factors, column (2) shows the variable, column (3) factor loading

\begin{tabular}{|l|l|l|}
\hline Factors(1) & Variables(2) & $\begin{array}{l}\text { Factor } \\
\text { loadings } \\
\text { for } \\
\text { compone } \\
\text { nts(3) }\end{array}$ \\
\hline $\begin{array}{l}\text { Planning and } \\
\text { Organizationa } \\
1 \text { skills }\end{array}$ & $\begin{array}{l}\text { Planning and organizational } \\
\text { skills is first step in } \\
\text { employability skills } \\
\text { prediction }\end{array}$ & \\
\hline & $\begin{array}{l}\text { Manage the tasks } \\
\text { successfully }\end{array}$ & 0.658 \\
\hline & $\begin{array}{l}\text { Motivation and ultimate } \\
\text { success }\end{array}$ & 0.702 \\
\hline
\end{tabular}

Time management and 0.594 planning

\begin{tabular}{|c|c|c|}
\hline & $\begin{array}{l}\text { Increase self-motivation } \\
\text { and potentially future } \\
\text { success }\end{array}$ & 0.559 \\
\hline \multirow{5}{*}{$\begin{array}{l}\text { Self } \\
\text { Management } \\
\text { Skills } \\
\end{array}$} & $\begin{array}{l}\text { Own behavior on a } \\
\text { self-checklist. }\end{array}$ & 0.576 \\
\hline & $\begin{array}{l}\text { Improving a wide range of } \\
\text { behaviors }\end{array}$ & 0.906 \\
\hline & Positive results/reviews & 0.585 \\
\hline & Self-monitoring & 0.634 \\
\hline & Self-evaluation & 0.783 \\
\hline \multirow{2}{*}{$\begin{array}{l}\text { Team work } \\
\text { skills }\end{array}$} & Teamwork abilities & 0.739 \\
\hline & Teamwork goals & 0.609 \\
\hline \multirow{4}{*}{$\begin{array}{l}\text { Communicati } \\
\text { on skills }\end{array}$} & Oral & \\
\hline & Written & \\
\hline & Good Communication & 0.759 \\
\hline & Patient Communication & 0.94 \\
\hline \multirow{5}{*}{$\begin{array}{l}\text { Problem } \\
\text { solving skills }\end{array}$} & Very effective & 0.433 \\
\hline & $\begin{array}{l}\text { No rules for problem } \\
\text { solving }\end{array}$ & \\
\hline & $\begin{array}{l}\text { Good level of collaboration } \\
\text { helps problem solving }\end{array}$ & 0.962 \\
\hline & Experience & 0.413 \\
\hline & $\begin{array}{l}\text { Find the solution, at least in } \\
\text { the tasks of the retrieval of } \\
\text { unusual words and rebus } \\
\text { problem solving }\end{array}$ & 0.947 \\
\hline \multirow[t]{4}{*}{$\begin{array}{l}\text { Technologica } \\
\text { 1 Skills }\end{array}$} & Improve our knowledge & 0.751 \\
\hline & Daily life & 0.44 \\
\hline & Employee motivation & 0.4 \\
\hline & Struggling employees & 0.44 \\
\hline
\end{tabular}

The table 7 explained that among 29 items only 25 items were loaded more than 0.4 values with relevant factors. The High level of cooperation 
within my team - TWS 2, All team members treated me fairly - TWS3, Satisfied with performance of my team - TWS 5 and The technology skills has not used for all the area - TS 1 were extracted on the factor analysis. The loaded 25 items were influences the employability skills on the employee performance, further theses variables were taken over for the further study.

\section{CONCLUSION}

Based on the finding it's empirically proven that the employability skills strongly influence on the employee performance. The employee skills concerned their importance of the employability skills in industry sector. The study has focused the three objectives. The first objective is analyzing the relationship between the self management skills and employee performance of the industrial employee. The statistically data proven that the positive results/reviews is highly correlated with the employee performance with Pearson coefficient value of 0.804 . The second objective is to measure the impact of employability skills on employee performance. For this the regression results reveals that among 29 employability skills predictors the 19 predictors were significant with the employee performance. The result clearly seems that there is an impact of employability skills over employee performance. The third objective is to identify the factors influencing the employability skills in the industrial employees. The exploratory analysis reveals that among 29 items the 25 items were loaded in the 6 classified factors. Thus all the objectives of the research were statistically proven with the collected primary data. The overall implication of the study is suggested that the employability skills of the industrial employee have direct effect on employee performance. Hence, the industrial sector employer should give more attention and focus by providing the employability skills training among the Industrial employee to get better performance from the employee.

\section{REFERENCES}

1. Overtoom, C (2000), Employability Skills: An Update. ERIC Digest No.220. Columbus: ERIC Clearinghouse on Adult, Career, and Voca-tional Education, the Ohio State University, (ED 445 236)http://www.ericacve.org/digests.asp

2. Rasul et al (2010), "Development Of Employability Skills Assessment Tool For Manufacturing Industry”, Jurnal Mekanikal, Vol. No. 30, pp $48-61$

3. Vidya M. Iyer, Kartik Dave, (2015) "Industry's role in employability", Industrial and Commercial Training, Vol. 47 Issue: 3, pp.151-158.

4. SamsonPackianathan and Rajagopal Narayanan, R. (2014), "Employability Skills: a Conceptual Framework", International Journal of Management, Vol. 5(7), pp 73-80.

5. Divya Shukla (2012), "Employability Skill among Professionals Chagrin of HR Executives in Indian Labor Market: A Study on Engineering Graduates of Bhopal City", International Journal of Business \& Mgmt. Research, Vol. 2 (8),

6. Faize Nabi (2013), "Management Students' Self-perception towards their Employability Skills - A Pre and Post Soft Skills Training Analysis “ International Research Journal of Business and Management - IRJBM , Vol IV, pp 1-12.

7. Sung, Johnny and NG, Chi Man and Loke, Fiona and Ramos, Catherine R. (2013), "The Nature of Employability Skills: Empirical Evidence from Singapore", Special Issue on Basic and Employability Skills. Edited by Linda Miller, Andy Biggart and Becci Newt, Vol. 17, Issue 3, pp. 176-193, 2013.
8. Robinson, J.P. (2000, 15 September), "What are Employability Skills?", Alabama Cooperative Extension system. Retrieved from , http://www.fremont.k12.ca.us/cms,

/lib04/CA01000848/Centricity/Domain/189/employability-skills.pdf. 